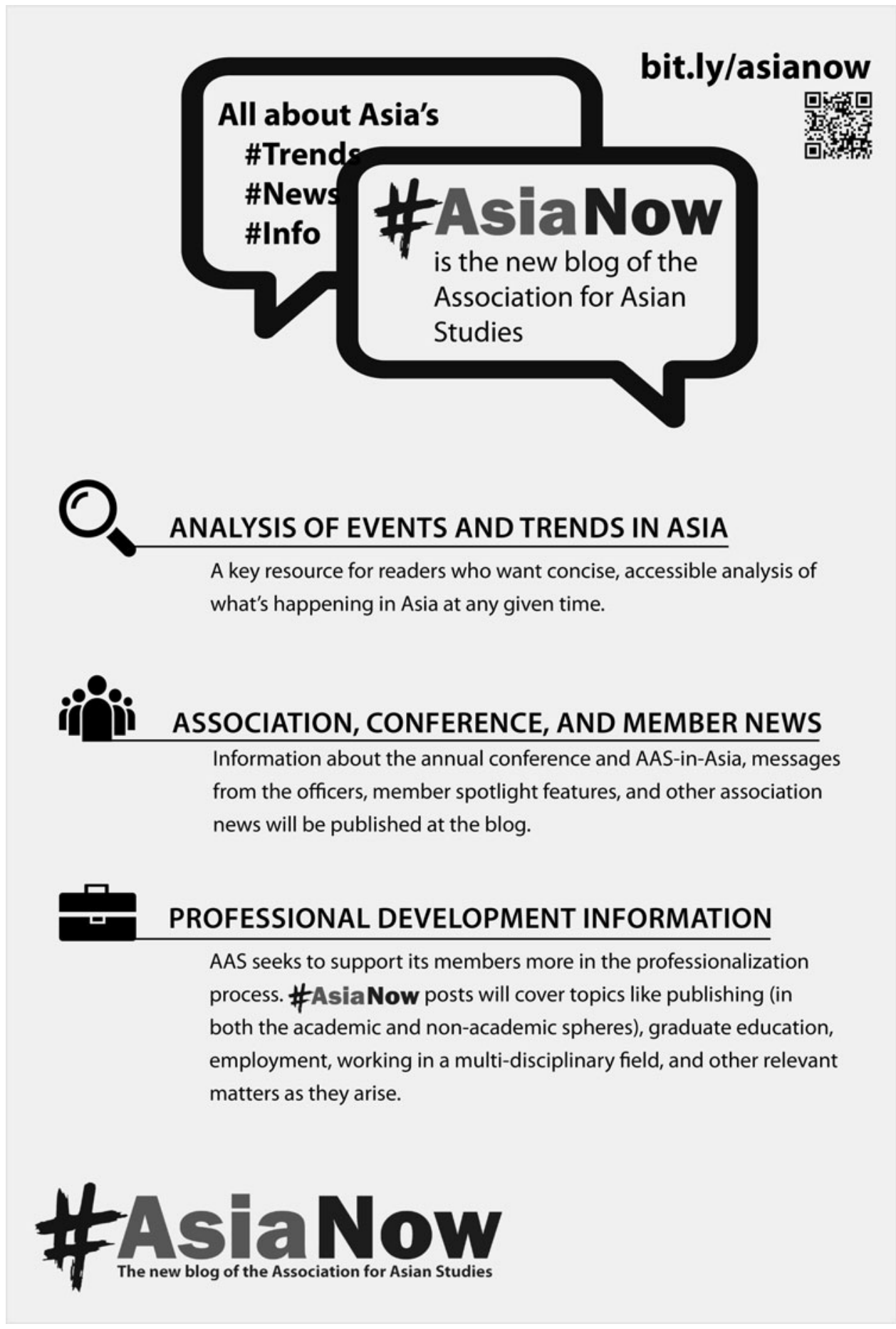




\section{NHK WORLD-JAPAN}

NHK WORLD, the international broadcasting service of NHK, made a fresh start as NHK WORLD-JAPAN this April.

Our English-language TV channel offers a variety of programs - from news, business, travel to arts and culture.
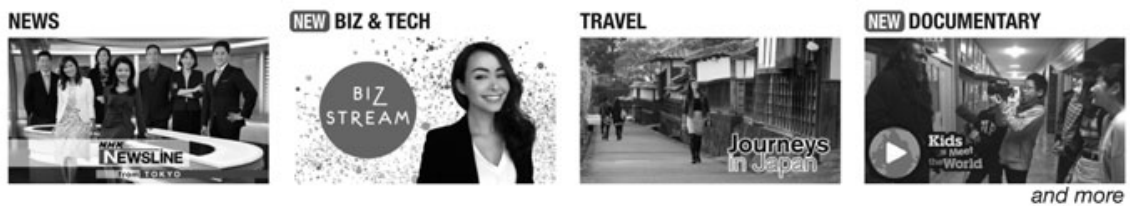

\section{How To Watch NHK WORLD-JAPAN}

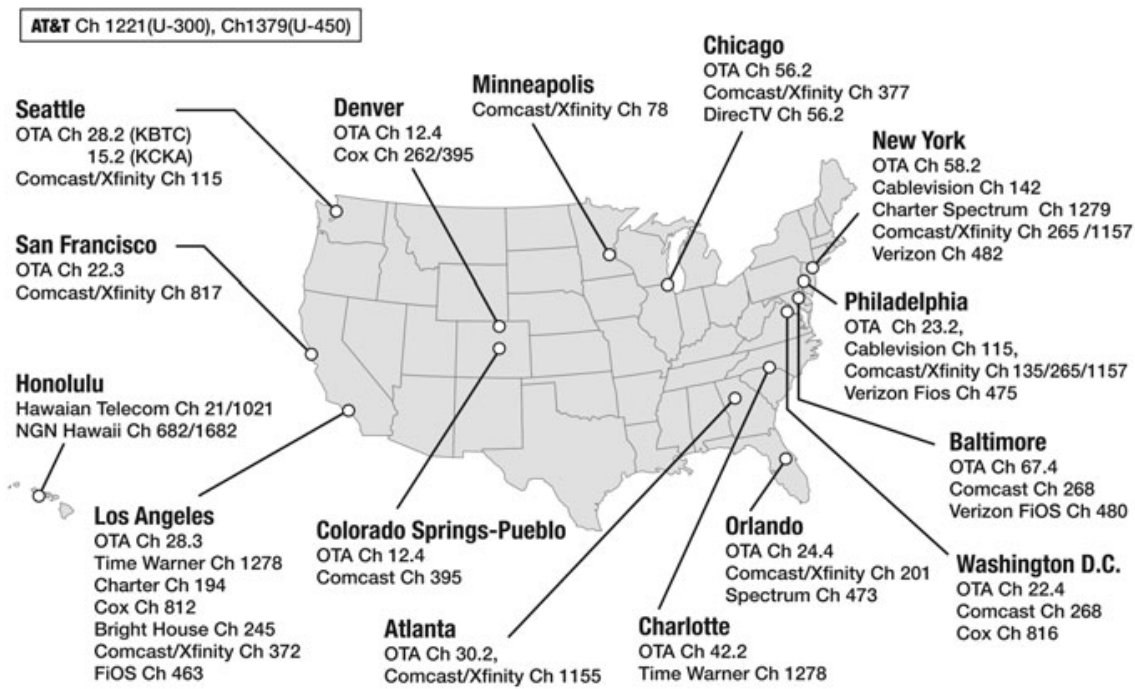




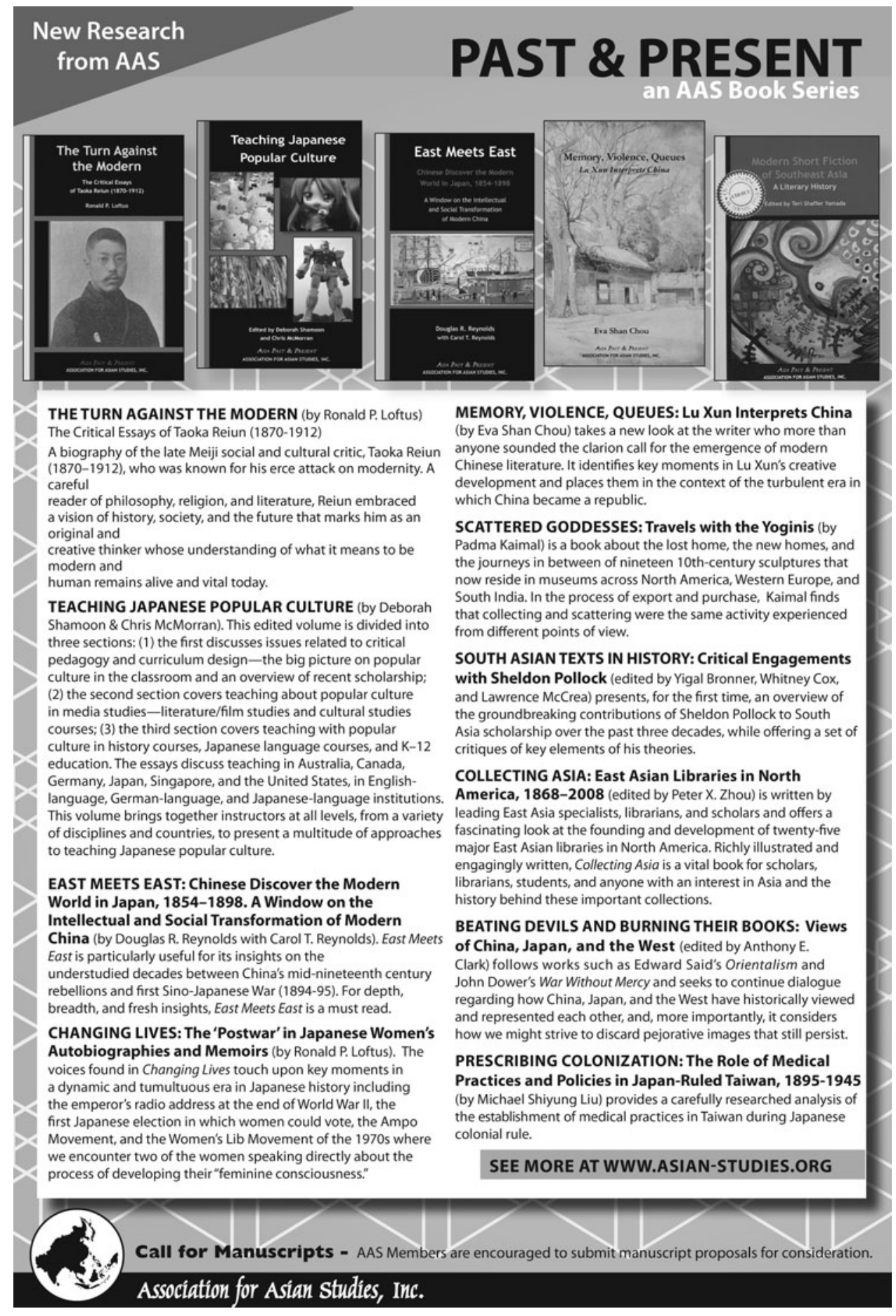




\section{EDUCATION ABOUT ASIA}

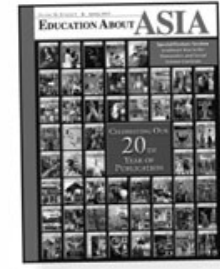

ExcanowABoctASIA

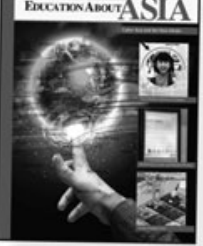

весапен AowASIA

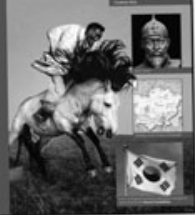

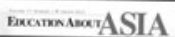
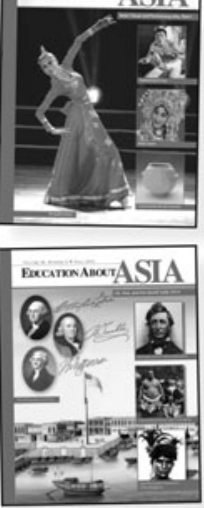

\section{AVAILABLE IN PRINT AND ONLINE OPEN ACCESS}

Browse the tables of contents and access over 1,500 articles from all published issues on the Education About Asia website, www.asian-studies.org/EAA

This expanded availability of Education About Asia is an exciting prospect for all who are interested in improving the understanding of Asia in secondary schools, community colleges, and colleges and universities.

Help us promote Education About Asia by informing your colleagues, students, educators, and librarians about this excellent teaching resource.

\section{SUBSCRIBE TO THE PRINT EDITION}

Please continue to support Education About Asia by subscribing to or renewing your subscription to the print edition which is published three times a year.

Education About Asia is a unique and innovative journal - a practical teaching resource for secondary school, college, and university instructors, as well as an invaluable source of information for students, scholars, libraries, and anyone with an interest in Asia. Education About Asia brings you:

- Articles on all areas of Asia, with subjects ranging from ancient cultures and literatures to current affairs.

- Essays describing classroom-tested educational programs and strategies.

- A comprehensive guide to Asia-related print and digital resources, including movies, documentaries, books, curriculum guides, and web resources.

- Thematic issues on topics of particular interest, such as cyber Asia and new media, food and culture in Asia, field trips, youth culture, popular culture, religion in Asia, marriage and family in Asia, economics and business, visual and performing arts, and Asia in world history. "The most important single resource for teachers in the entire field of Asian Studies."
Richard J. Smith, Rice University

"The best publication in the market for teachers interested in teaching about Asia" Douglas P. Sjoquist, Lansing Community College

"A wealth of timely and well-written material on topics of deep importance to our global world." Patience Berkman, Newton Country Day School

\section{UPCOMING THEMATIC ISSUES}

SPRING 2018 (23:1) Asian Politics

FALL 2018 (23:2) Demographics, Social Policy, and Asia (Part II)

WINTER 2018 (23:3) What Should We Know About Asia?

For subscription information, contact Lisa Hanselman, Ihanselman@asian-studies.org, and for advertising questions, please e-mail ads@asian-studies.org or call the AAS office at (734) 665-2490.

Access online articles and subscribe to the print edition of Education About Asia at www.asian-studies.org/EAA 
A NEW BOOK SERIES FROM AAS

\section{ASIA SHORTS}

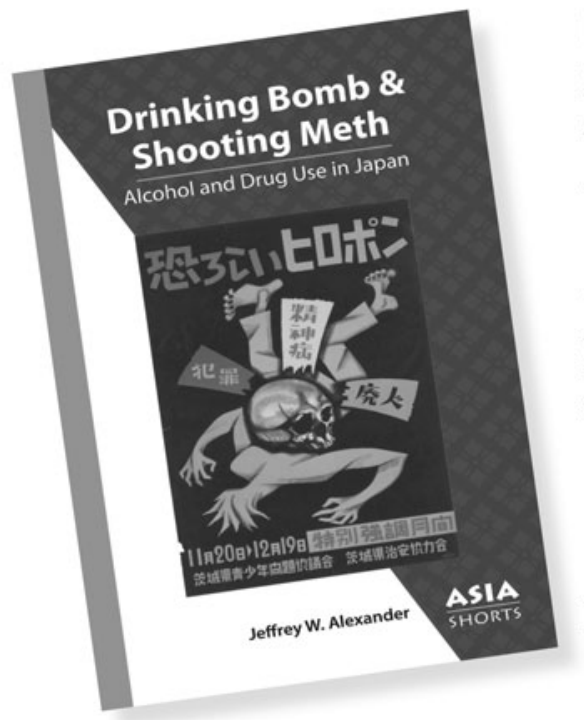

\section{DRINKING BOMB \&} SHOOTING METH

Alcohol and Drug Use in Japan

Jeffrey W. Alexander

"A masterful analysis of modern Japanese alcohol and drug culture ... a must-read scholarly study, with details alternately humorous and horrific."

- Norman Smith, University of Guelph and author, Intoxicating Manchuria

\section{AVAILABLE NOW FROM AAS Www.asian-studies.org}

"ASIA SHORTS" will offer concise, engagingly-written titles written by highly-qualified authors on topics of significance in Asian studies. Topics are intended to be substantive, generate discussion and debate within the field, and attract interest beyond it.

The AAS is exploring new ways of making rigorous, timely, and accessible work by scholars in the field available to a wide audience of informed readers. This new series will complement and leverage the success of the pedagogically-oriented AAS series, "Key Issues in Asian Studies" and will be designed to engage broad audiences with upto-date scholarship on important topics in Asian studies.

\section{CALl For Proposals}

We are currently looking for qualified authors for "ASIA SHORTS." For further information, consult the "ASIA SHORTS" author guidelines on the AAS website at www.asian-studies.org/Publications/ASIA-Shorts.

To discuss a proposal, contact the series editor, Bill Tsutsui, at tsutsui@hendrix.edu. 


\section{Association for Asían Studies 2019 ANNUAL CONFERENCE}

\section{MARCH 21-24, 2019}

SHERATON DENVER DOWNTOWN HOTEL,

\section{DENVER, COLORADO}

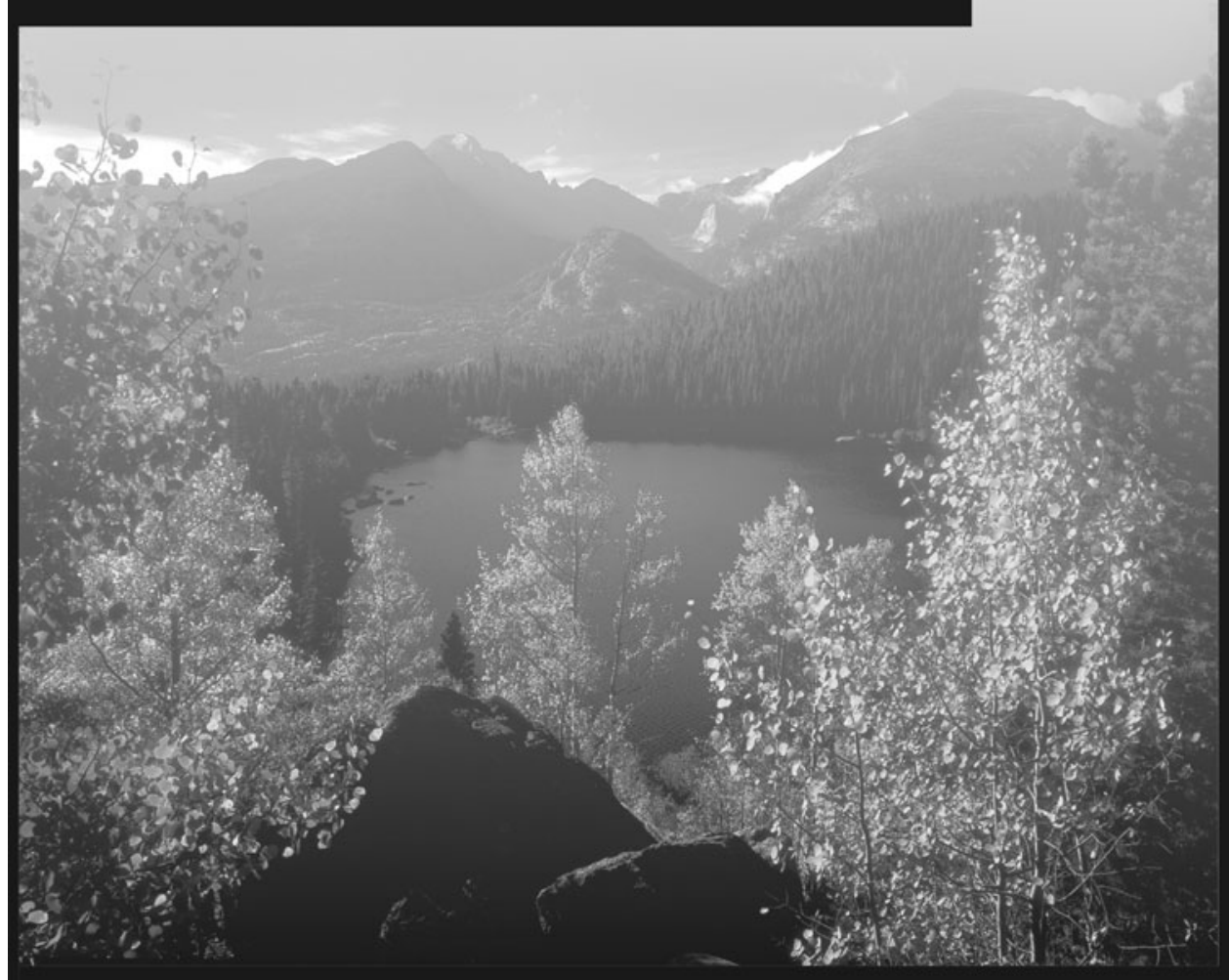

\section{CALL FOR PROPOSALS OPEN IN MAY}




\section{Key Issues in Asian Studies}

"Key Issues" volumes are designed for use in undergraduate humanities and social science courses, by advanced high school students/ teachers, and for anyone with an interest in Asia. These books introduce students to major cultural/historical themes and encourage classroom debate/discussion. For further details, a complete list of titles, and ordering information, please visit www.asian-studies.org

\section{NEW FOR 2018}

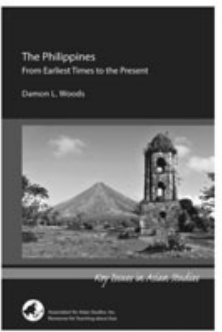

The Philippines

Damon Woods

\section{ALSO AVAILABLE}

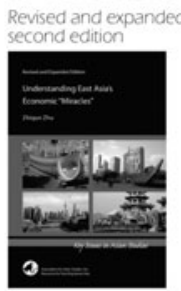

Understanding East

Asia's Economic

"Miracles"

Zhiqun Zhu

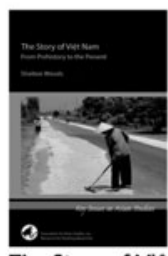

The Story of Việt Nam: From Prehistory to

the Present

Shelton Woods

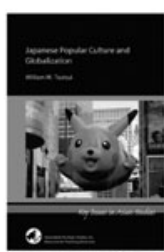

Japanese Popular

Culture and

Globalization

William M. Tsutsui

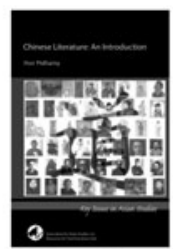

Chinese Literature: An Introduction Ihor Pidhainy

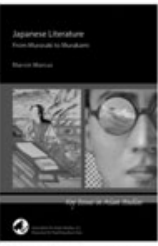

Japanese Literature: From Murasaki to

Murakami

Marvin Marcus

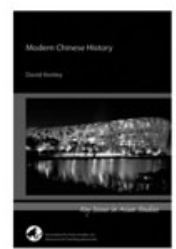

Modern Chinese History

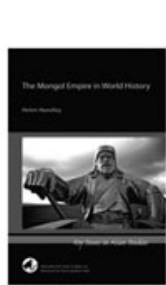

The Mongol Empire in World History Helen Hundley

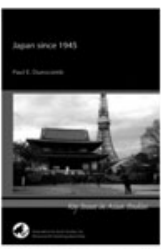

Japan since 1945 Paul E. Dunscomb

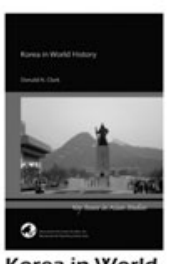

Korea in World History

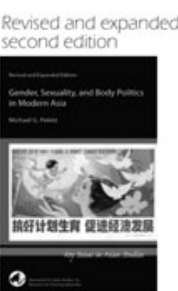

Gender, Sexuality, and Body Politics in Modern Asia Michael Peletz

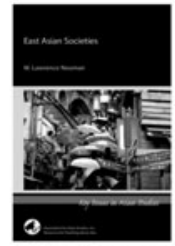

East Asian Societies W. Lawrence Neuman

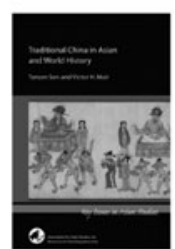

Traditional China in Asian and World

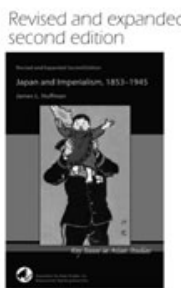

Japan and Imperialism: 1853-1945

James L. Huffman

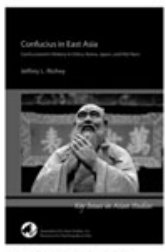

Confucius in East Asia Jeffrey L. Richey

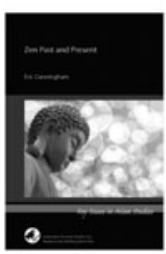

Zen Past and Present Eric Cunningham 


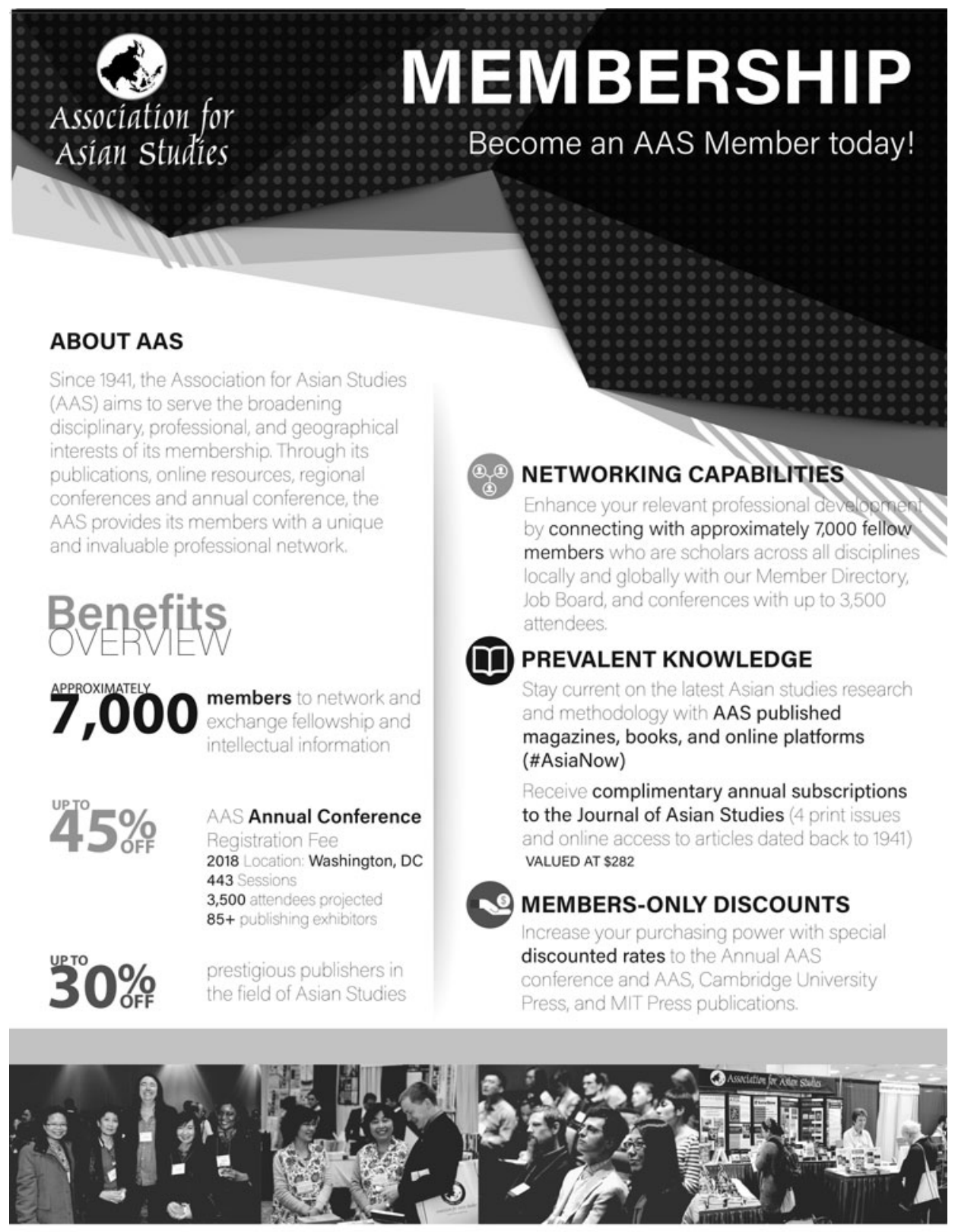

WWW.ASIAN-STUDIES.ORG 


\section{NEW PUBLICATIONS FROM THE HARVARd University ASIA Center}

An Introduction to Chinese Poetry

From the Canon of Poetry to the

Lyrics of the Song Dynasty

Michael A. Fuller

494 pp. hardcover $\$ 65.00$; pbk $\$ 45.00$

Building for Oil

Daqing and the Formation of the

Chinese Socialist State

Hou Li

267 pp. 48 halftones, 1 illustration, \& 7 maps hardcover $\$ 39.95$

\section{Revolutionary Waves}

The Crowd in Modern China

Tie Xiao

302 pp. 2 figures, hardcover $\$ 49.95$

Reading Philosophy, Writing Poetry

Intertextual Modes of Making Meaning

in Early Medieval China

Wendy Swartz

318 pp. hardcover $\$ 49.95$

Speaking of Profit

Bao Shichen and Reform in

Nineteenth-Century China

William T. Rowe

230 pp. 2 figures, hardcover $\$ 39.95$

Navigating Semi-Colonialism

Shipping, Sovereignty, and Nation-Building

in China, 1860-1937

Anne Reinhardt

396 pp. 7 figures, 5 maps, \& 1 table

hardcover $\$ 49.95$

\author{
The Halberd at Red Cliff \\ Jian'an and the Three Kingdoms \\ Xiaofei Tian \\ 470 pp. 1 map \\ hardcover $\$ 49.95$
}

The Anime Boom

in the United States

Lessons for Global Creative Industries

Michal Daliot-Bul \& Nissim Otmazgin

8 color plates, $5 \mathrm{~B} / \mathrm{W}$ figures, 2 tables

238 pp. hardcover $\$ 39.95$

\section{Legal Lessons}

Popularizing Laws in the People's Republic of China, 1949-1989

Jennifer Altehenger

408 pp. 25 figures, hardcover $\$ 49.95$

Ennobling Japan's Savage Northeast

Töboku as Postwar Thought, 1945-2011

Nathan Hopson

379 pp. 5 figures \& 4 maps, hc $\$ 49.95$

Give and Take

Poverty and the Status Order in

Early Modern Japan

Maren A. Ehlers

360 pp. 21 halftones, 5 maps, \& 4 tables hardcover $\$ 49.95$

Writing for Print

Publishing and the Making of Textual Authority in Late Imperial China

Suyoung Son

250 pp. 14 halftones, 1 table, hc $\$ 39.95$

Visit publications.asiacenter.harvard.edu for more information on our publications.

Our full backlist is now available on JSTOR.

Distributed by Harvard University Press

US $800405-1619$

www.hup.harvard.edu 


\section{Association for Asian Studies}

\section{A D V E R T IS E}

Choose the AAS for all your advertising needs and reach the largest Asian studies audience. Promote your organization, market your publications, introduce study programs, announce employment opportunities, and more!

\section{EDUCATION ABOUT ASIA}

- A unique and innovative publication.

- Articles on all areas of Asia.

- An invaluable source of information for students, educators, libraries, and anyone with an interest in Asia.

\section{JOURNAL OF ASIAN STUDIES}

- The most authoritative and prestigious publication in the field of Asian studies, published since 1941.

- Reach scholars and university libraries.

- Published February, May, August, and November for AAS by Cambridge University Press.

- Mailed four times per year to all AAS members and subscribers.

\section{AAS ANNUAL CONFERENCE}

- Reach over 3,000 attendees at the largest conference worldwide dedicated exclusively to Asian Studies. Reserve a Print Ad, E-flyer, Mobile App Sponsorship, and more.

\section{AAS JOB BOARD LISTINGS}

- Place your job listings on the AAS website for two months and search AAS member resumes.

\section{NEW! AAS BANNER ADS}

- Place banner ads on select pages of the AAS website.

\section{MAILING LISTS}

- Use AAS mailing labels to reach your Asian studies audience.

- Select from lists that are updated daily.

- Specialized sections available.

\section{NEW! AAS E-FLYER SERVICE}

- Let the AAS send out an email e-flyer to all AAS members on your behalf.

RESERVE SPACE TODAY!

\section{www.asian-studies.org}




\section{Support the Future of Asian Studies}

...and claim a tax deduction for 2018!

The Association for Asian Studies welcomes contributions to the following:

- The Wm. Theodore de Bary - Ainslie T. Embree Fund for Education and Outreach, to provide teaching resources to U.S. high schools and colleges through such publications as Education About Asia and Key Issues in Asian Studies.

- Fund for International Exchange, to enable scholars from Asia to attend AAS meetings and visit campuses.

- Fund for Young Scholars, to help graduate students to attend AAS meetings or dissertation workshops.

- Endowment Fund, to ensure the AAS's ability to support the study of Asia far into the future.

Find out more and make your donation today!

Visit www.asian-studies.org

The AAS is a $501(c)(3)$ corporation and contributions are tax deductible to the extent allowed by law!

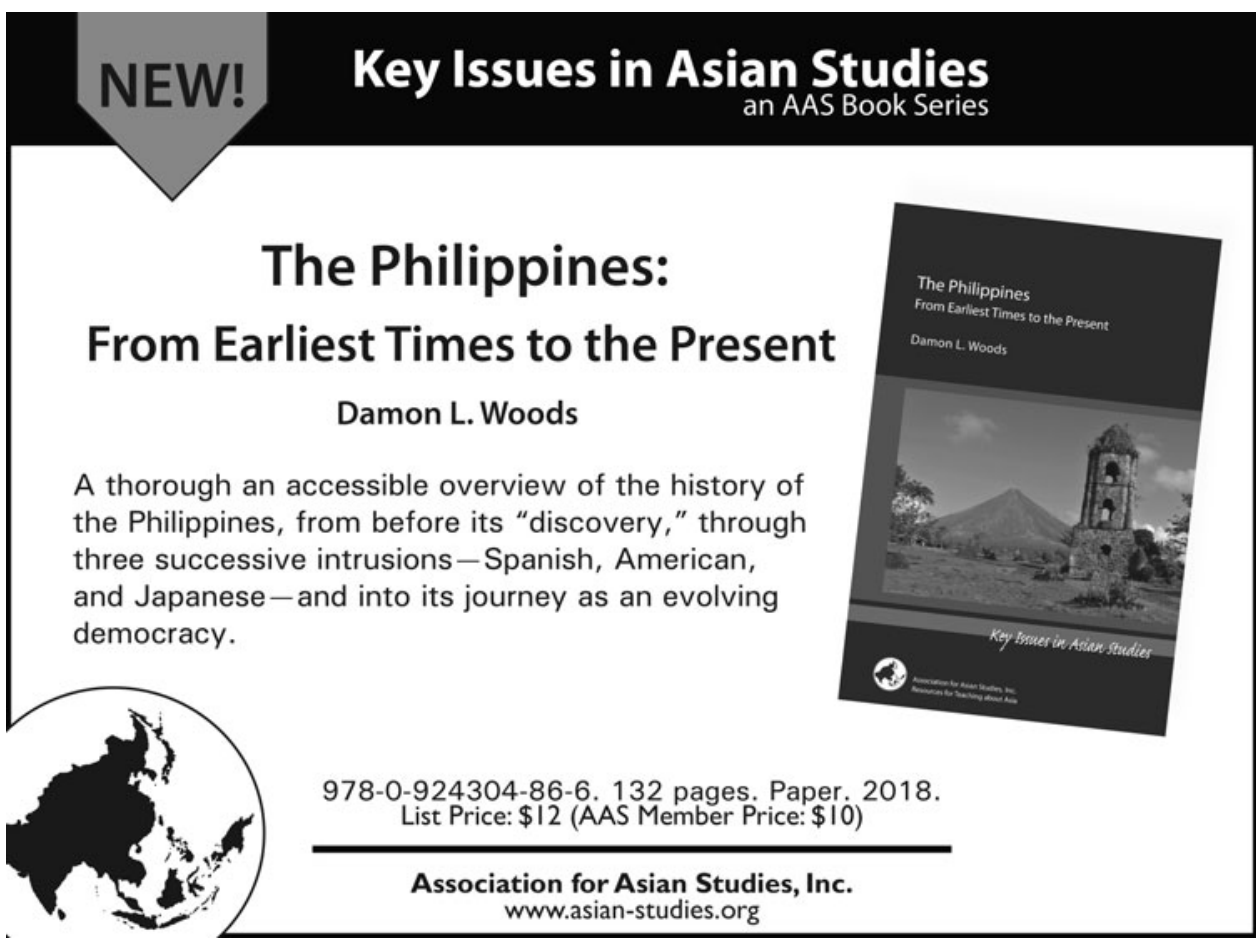




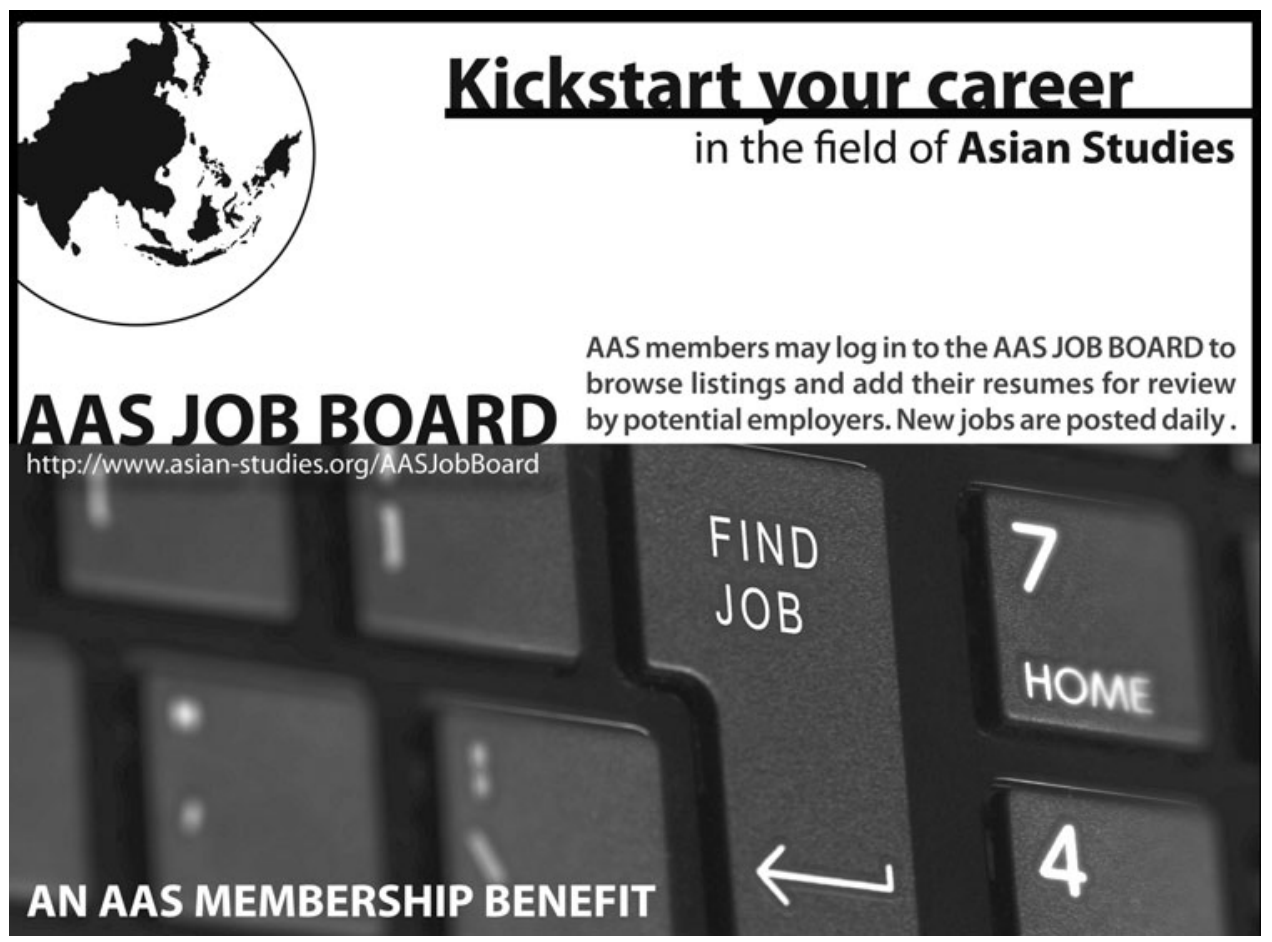

\section{Association for Asian Studies}

Celebrating Asian Studies in India

\section{AAS-IN-ASIA Conference}

\section{July 5-8, 2018}

India Habitat Centre

Ashoka University,

Delhi, India

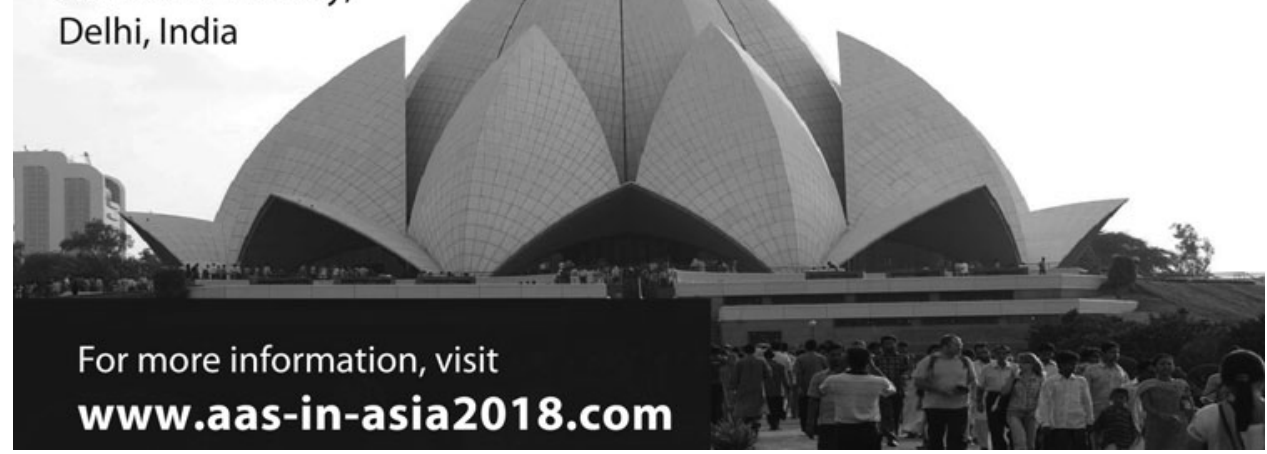




\section{The Journal of Asian Studies}

The Journal of Asian Studies (ISSN \#0021-9118) is published quarterly by the Association for Asian Studies, 825 Victors Way, Suite 310, Ann Arbor, MI 48108 USA. Periodicals postage paid at Ann Arbor, Michigan and additional mailing offices. Postmaster: send address changes to: The Journal of Asian Studies, Cambridge University Press, One Liberty Plaza, New York, NY 10006, USA.

Subscription Information: Annual subscription rates for Volume 77 (2018): Institutional subscription rates, print and online: US $\$ 269.00$ in the USA, Canada, and Mexico; UK $£ 163.00$ + VAT elsewhere. Institutional subscription rates, online only: US $\$ 254.00$ in the USA, Canada, and Mexico; UK $£ 154.00$ + VAT elsewhere. Individuals must be current members of the Association for Asian Studies (AAS) to receive the journal. AAS has a graduated dues structure; membership fees are based on gross income. For further information please visit www.asian-studies.org or call the AAS Membership Manager at (734) 665-2490. Single part prices: US $\$ 77.00$ in the USA, Canada, and Mexico; UK $£ 47.00$ + VAT elsewhere. Institutional subscription correspondence should be sent to: Cambridge University Press, One Liberty Plaza, New York, NY 10006, USA, for customers in the USA, Canada, or Mexico. Customers elsewhere should contact: Cambridge University Press, University Printing House, Shaftesbury Road, Cambridge, CB2, 8BS, UK.

Editorial Office: The Journal of Asian Studies, History Department, University of California, 200 Murray Krieger Hall, Irvine, CA, 92697-3275.

Abstracting and Indexing Information: Articles in The Journal of Asian Studies are indexed or abstracted in ABC-CLIO; Arts and Humanities Citation Index ${ }^{\circledR}$; Bibliography of Asian Studies; Current Contents ${ }^{\circledR} /$ Arts \& Humanities, Current Contents ${ }^{\circledR} /$ Social and Behavioral Sciences, Journal Citation Reports/Social Sciences Edition; European Reference Index for the Humanities and Social Sciences (ERIH PLUS); IBZ and IBR; MLA Bibliography; Revue Bibliographique de Sinologie; Social Sciences Citation Index; Sociological Abstracts.

Copyright (C) 2018 Association for Asian Studies, Inc. All rights reserved. No part of this publication may be reproduced, in any form or by any means, electronic, photocopy, or otherwise, without permission in writing from Cambridge University Press. General enquiries from the USA, Mexico, and Canada should be addressed to the New York office of Cambridge University Press http://www.cambridge.org/us/information/rights/ contacts/newyork.htm; general enquiries from elsewhere should be addressed to the Cambridge office http://www.cambridge.org/uk/information/rights/contacts/cambridge. htm; permission enquiries from Australia and New Zealand should be addressed to the Melbourne office http://www.cambridge.org/aus/information/contacts_melbourne.htm; enquiries regarding Spanish-language translation rights (only) should be addressed to the Madrid office http://www.cambridge.org/uk/information/rights/contacts/madrid.htm.

Photocopying information for users in the U.S.A.: The Item-Fee Code for the publication $(0021-9118 / 11 \$ 15.00+.10)$ indicates that copying for internal or personal use beyond that permitted by Sec. 107 or 108 of the U.S. Copyright Law is authorized for users duly registered with the Copyright Clearance Center (CCC) Transaction Reporting Service, provided that the appropriate remittance of $\$ 15.00$ per article is paid directly to CCC, 222 Rosewood Drive, Danvers, MA 01923. Specific written permission must be obtained for all other copying. 


\section{CONTACT INFORMATION: BOOKS FOR REVIEW}

Please note that the Journal of Asian Studies does not accept unsolicited book reviews.

If you are interested in reviewing books selected by a Book Review Editor, please complete our reviewer survey, found at: https://docs.google.com/forms/d/e/1FAIpQLSd3tlyVF For more information on books received and books reviewed, please visit http://journalofasianstudies.org. Please direct correspondence regarding books and book reviews to: jasoffice@journalofasianstudies.org or by phone: (949) 824-6521 for matters pertaining to books and book reviews.

Please send books for review by the Journal of Asian Studies to the following Book Review Editors based on regional categorization. Please do not send books to the JAS Editorial Office.

\section{Asia Comparative/Transnational:}

(includes comparison between Asia/Asian countries and other regions of the globe, and also includes books that cover multiple Asian countries, e.g. Korea and Japan, China and Vietnam, etc.)

Heather Hindman

The University of Texas at Austin

Department of Asian Studies

120 Inner Campus Drive

Stop G9300

Austin, Texas, 78712-1251

\section{China, Pre-1900:}

(also includes Hong Kong and Taiwan)

Paola Zamperini

Northwestern University

Asian Languages and Cultures

Kresge Hall

1880 Campus Drive, 4th Floor

Evanston, IL 60208

\section{China, 1900-Present:}

(also includes Hong Kong and Taiwan)

Aminda Smith

Michigan State University

Department of History

506 E. Circle Dr., Rm 214

East Lansing, MI 48824

\section{Inner Asia:}

(includes Mongolia, Tibet, Xinjiang)

Rian Thum

Dept. of History, Loyola University New Orleans Campus Box 191, 6363 St. Charles Ave.

New Orleans, LA 70118

\section{Japan:}

Mark Ravina

Dept. of History, Emory University

561 South Kilgo Circle NE, Bowden Hall, Room 221

Atlanta, GA 30322-3651

\section{Korea:}

Kyung Moon Hwang

Professor

Department of History, USC

3520 Trousdale Pkwy. \#279

Los Angeles, CA 90089-0034

\section{South Asia:}

(includes Bangladesh, Bhutan, India, Nepal, Pakistan, and Sri Lanka)

Arjun Guneratne

Department of Anthropology

1600 Grande Avenue

Macalester College

Saint Paul, MN 55105

\section{Southeast Asia:}

(includes Brunei, Cambodia, East Timor, Indonesia, Laos, Malaysia, Myanmar/Burma, the Philippines, Singapore, Thailand, and Vietnam)

Muhamad Ali and David Biggs

SE Asia Book Review Editors

c/o Katharine Henshaw

Center for Ideas and Society

College Building South

900 University Ave.

Riverside, CA 92521 


\section{PROCEDURE FOR MANUSCRIPT SUBMISSION}

Manuscripts of 8,000 to 10,000 words and any accompanying figures should be submitted electronically through the Editorial Manager online submission system (http://www.editorialmanager.com/jas/). If needed, the Editorial office can be reached via email: jas@journalofasianstudies.org or by phone: (949) 824-6521.Lowresolution images and illustrations are acceptable for the review process; all images, tables and figures should include titles or captions. Please note that in the event of publication, the author is responsible for acquiring high-resolution images along with permission to publish them.

All authors who wish to include figures should read and follow the Cambridge Artwork Guide, available at https://journals.cambridge.org/action/stream?pageId=7848\&level=2\&menu=Authors\&pageId=3608.

Due to the volume of submissions, we cannot evaluate proposed abstracts or titles, only full submissions. The JAS does not do special issues.

See the AAS website (https://www.asian-studies.org/Publications/JAS), Cambridge Core (cambridge.org/jas), and Editorial Manager (http://www.editorialmanager.com/jas/default.aspx) for more information on the journal, types of work we publish, and sample articles.

\section{REQUIREMENTS FOR MANUSCRIPT SUBMISSION}

When preparing a manuscript, please note that JAS is committed to publishing articles based on in-depth, original research. Authors should also take care to address the interests of our broad, multidisciplinary readership by raising larger questions of interest that reach beyond their precise research specialties. Authors are encouraged to consult recent issues of JAS for guidance on style and formatting.

- Manuscripts submitted to JAS should not have been published elsewhere and should not be under review for publication elsewhere.

- Article manuscripts, including notes and references, should range between 8,000 and 10,000 words, or approximately thirty-five pages in length, and must include a 150 word abstract at the beginning of the document.

- Authors' names must be left off of the manuscript, as JAS engages in double-blind reviews.

- Please double-space manuscripts and use 12-point type with 1 inch margins including abstracts, notes, and references.

- Notes should be as few as possible and appear at the end of the text

- Use parenthetical in-text citation, and author-date formatting for references per section 15 of the Chicago Manual of Style, 16th edition (Chicago: University of Chicago Press, 2010).

- Please use the following Romanization: Chinese: Pinyin; Japanese: Hepburn; Korean: McCune-Reischauer.

Articles in JAS represent neither the views of the Association for Asian Studies nor those of the JAS editors. The Editor is responsible for the final selection of content of JAS and reserves the right to reject any material deemed inappropriate for publication. Responsibility for opinions expressed and the accuracy of facts published in articles and reviews rests solely with the individual authors.

\section{THE ONE OVER RULE AND OTHER THOUGHTS ON SUBMITTING TO THE JOURNAL OF ASIAN STUDIES}

Jeffrey Wasserstrom

Editing the JAS is an exciting job but also a daunting job. It is exciting because so many fascinating pieces get sent in for consideration, but it is daunting because so few of these can be published. There is no magic formula used to determine which 25 or so of the well over 300 submissions we get in any given year end up being accepted, but over the course of my four years as Editor, I have come up with some rules of thumb. Since the Journal's Managing Editor Jennifer Munger and I are often asked questions by authors trying to assess their chances of having their article accepted, it seems worth spelling out some of these:

1) There are more pieces that qualify as the very best articles on Asia than we have room to publish. Our goal, therefore, is to select articles that are of very high quality and that, when taken together, make for individual issues and yearly volumes that seem likely to strike our readers as interesting and attractively varied.

2) The One Over Rule. In an ideal world, every JAS article would be accessible and appealing to all members of the Association for Asian Studies, the group that remains our primary target readership. More realistically, I am determined that nothing run under my watch will only be of interest to scholars working in a single discipline and on a single period or locale, and that nothing will only make sense to a small segment of the AAS membership, due to the terminology or formulae used. A lot of excellent articles are highly specialized and intended simply for others who are expert in an area, but there are many good journals where such work can be published. The JAS, by contrast, is an interdisciplinary general journal. To work for us, an article has to, at the very least, be something that scholars in two or three different disciplines will be able to understand easily and that will have the potential at least to interest readers working on neighboring countries, related topics, and on adjacent periods. Articles do not need to be comparative or interdisciplinary. They do need to have a broad as opposed to narrow aspect to them. Hence, the "one over rule," which means an ability to speak to someone in a field close to the author's own. An article by, say, an anthropologist working on Laos need not have any obvious appeal to a literary critic specializing in the study of Korea, but if this piece would have no chance of drawing the interest of a sociologist whose focus is Cambodia, we have a problem. Similarly, while that imagined Korean literature specialist does not have to write a piece that is certain to draw in an economist primarily concerned with India, there's a problem if Japanese studies scholars working in cultural studies do not think it speaks in any way to them. The same kind of thinking applies to periods as to places and disciplines. 


\section{Reflections}

Hugh R. Clark

What's the Matter with "China"? A Critique of Teleological History

\section{War and Environment on the Korean Peninsula}

Albert L. PARK

Introduction to a Forum on War and Environment on the

Korean Peninsula, 1598-1965

JOHN S. LEE

Postwar Pines: The Military and the Expansion of State Forests in

Post-Imjin Korea, 1598-1684

DAVID FEDMAN

Wartime Forestry and the "Low Temperature Lifestyle" in Late

Colonial Korea, 1937-1945

LISA M. BRADY

Sowing War, Reaping Peace: United Nations Resource Development Programs in the Republic of Korea, 1950-1953

Albert L. PARK

The Reshaping of Landscapes: Systems of Mediation, War, and Slow Violence

Micah S. Muscolino

Woods and Warfare in Korea and the World: A View from China

\section{Research Articles \\ YosHINORI NISHIZAKI}

New Wine in an Old Bottle: Female Politicians, Family Rule, and

Democratization in Thailand

Jeremy Jammes and David A. PALmer

Occulting the Dao: Daoist Inner Alchemy, French Spiritism, and

Vietnamese Colonial Modernity in Caodai Translingual Practice

FLORIAN SCHNEIDER

Mediated Massacre: Digital Nationalism and History Discourse on China's Web

Timothy Thurston

A Careful Village: Comedic Dialogues and Linguistic Modernity in China's Tibet

Aya H. Kimura

Hungry in Japan: Food Insecurity and Ethical Citizenship 